considered, for ADG, as a consequence of group-feeding the two sibs in a common pen and, for meat quality traits, as an effect of the «common slaughter-day environment », as the two sibs were usually slaughtered on the same day. Phenotypic and genetic correlations between ADG and FCR were lower than the usual estimates under individual feeding. The genetic correlations between meat quality and the other traits were low, the highest one being obtained for FCR $(0.23 \pm 0.16)$.

\title{
A first evaluation of the Duroc breed
}

\author{
P. SELLIER \\ I.N.R.A., Station de Génétique quantitative et appliquée, \\ Centre de Recherches zootechniques, \\ F 78350 Jouy-en-Josas
}

The Duroc (D) breed was compared to the Piétrain (P), Belgian Landrace (B) and Hampshire $(\mathrm{H})$ breeds in terms of their respective merit as sire line of a 3 way-cross involving French Landrace $\times$ Large White dams. Fattening and carcass data were recorded on 573 pigs sired by a number of boars from the 4 breeds $(10 \mathrm{P}, 15 \mathrm{~B}, 13 \mathrm{H}$ and $11 \mathrm{D}$ boars) and fed ad libitum from 32 to $101 \mathrm{~kg}$ liveweight. Means of XP $(\mathrm{n}=141), X B(\mathrm{n}=144)$, $\mathrm{XH}(\mathrm{n}=140)$ and $\mathrm{XD}(\mathrm{n}=148)$, pigs respectively were (two means with the same superscript are not different at the 5 p. 100 level) : $728^{\mathrm{a}}, 792^{\mathrm{l}}, 845^{\prime}$ and $801^{\mathrm{l}}$ for average daily gain (g) ; $2.62^{\mathrm{a}}, 2.78^{\mathrm{b}}, 2.95^{\mathrm{c}}$ and $2.86^{\mathrm{l} c}$ for daily feed consumption $(\mathrm{kg}) ; 3.66^{\mathrm{a}}, 3.54^{\mathrm{a}}, 3.51^{\mathrm{a}}$ and

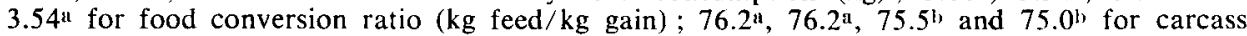
weight $(\mathrm{kg}) ; 94.7^{\mathrm{a}}, 98.2^{\mathrm{c}}, 96.3^{\mathrm{b}}$ and $96.9^{\mathrm{b}}$ for carcass length $(\mathrm{cm}) ; 24.5^{\mathrm{a}}, 24.7^{\mathrm{a}}, 25.0^{\mathrm{a}}$ and $24.4^{\mathrm{a}}$ for average backfat thickness $(\mathrm{mm}) ; 53.5^{\mathrm{a}}, 52.9^{\mathrm{ab}}, 52.5^{\mathrm{ab}}$ and $52.0^{\mathrm{b}}$ for estimated lean percentage. In ultimate $\mathrm{pH}$ and colour of meat, the $\mathrm{XH}$ type differed $(p<0.01)$ from the three other genetic types which gave similar results in this respect : meat from XH pigs exhibited a lower ultimate $\mathrm{pH}$ and a paler colour. The overall economic merit of the pigs from the four 3 way crosses was estimated, taking into account fattening cost and commercial value of the carcass : on this basis, the $\mathrm{XB}$ and $\mathrm{XH}$ types were similar and both were better than the $X D$ and, to a greater extent, $X P$ types. This first evaluation of the Duroc suggests that this breed has not to play a major part as a sire breed or as a component of a crossbred boar for terminal crossing, at least in the present conditions of pig production in France.

\section{Comparative study on the reproductive performance, fattening performance and carcass quality of Creole and Large White pigs in Guadeloupe}

\author{
I. CANOPE et Y. RAYNAUD \\ I.N.R.A., Station de Recherches zootechniques, \\ Antilles-Guyane, 97170 Petit-Bourg, Guadeloupe \\ Ingénieur Agronome de l'E.N.S.A., Toulouse \\ (Volontairc à l'Aide Technique en Guadeloupe), France
}

\begin{abstract}
Reproductive performance of a sample of Large White sows imported from France was compared to those of a local breed (Créoles).

Age and weight at puberty were 171.4 days and $52.3 \mathrm{~kg}$, respectively for the local breed and 275 days and $107 \mathrm{~kg}$ for the Large White pig, but no difference was observed between weaning-oestrus and weaning-successful mating.
\end{abstract}

